\title{
Effect of GP19 Peptide Hyperimmune Antiserum on Activated Macrophage during Ehrlichia canis Infection in Canine Macrophage-like Cells
}

\author{
Boondarika Nambooppha ${ }^{1}\left[\right.$, Amarin Rittipornlertrak ${ }^{1}$, Anucha Muenthaisong ${ }^{1}$, Pongpisid Koonyosying ${ }^{1}$, \\ Sahatchai Tangtrongsup ${ }^{2}\left(\mathbb{D}\right.$, Saruda Tiwananthagorn ${ }^{1}\left(\mathbb{D}\right.$, Yang-Tsung Chung ${ }^{3}$ and Nattawooti Sthitmatee ${ }^{1,4, *(\mathbb{1})}$
}

Citation: Nambooppha, B.; Rittipornlertrak, A.; Muenthaisong, A.; Koonyosying, P.; Tangtrongsup, S.; Tiwananthagorn, S.; Chung, Y.-T.; Sthitmatee, N. Effect of GP19 Peptide Hyperimmune Antiserum on Activated Macrophage during Ehrlichia canis Infection in Canine Macrophage-like Cells. Animals 2021, 11, 2310. https://doi.org/10.3390/ ani11082310

Academic Editor: Simon L. Priestnall

Received: 17 June 2021

Accepted: 3 August 2021

Published: 5 August 2021

Publisher's Note: MDPI stays neutral with regard to jurisdictional claims in published maps and institutional affiliations.

Copyright: (c) 2021 by the authors. Licensee MDPI, Basel, Switzerland. This article is an open access article distributed under the terms and conditions of the Creative Commons Attribution (CC BY) license (https:/ / creativecommons.org/licenses/by/ $4.0 /)$.
1 Department of Veterinary Biosciences and Veterinary Public Health, Faculty of Veterinary Medicine, Chiang Mai University, Chiang Mai 50100, Thailand; boondarika.n@gmail.com (B.N.); mate_vet@hotmail.com (A.R.); anucharham@gmail.com (A.M.); pk404mc@hotmail.com (P.K.); stiwananthagorn@gmail.com (S.T.)

2 Department of Companion Animals and Wildlife Clinics, Faculty of Veterinary Medicine, Chiang Mai University, Chiang Mai 50100, Thailand; sahatchai.t@cmu.ac.th

3 Department of Veterinary Medicine, College of Veterinary Medicine, National Chung Hsing University, Taichung 402, Taiwan; rjchung_097@yahoo.com.tw

4 Excellence Center in Veterinary Bioscience, Chiang Mai University, Chiang Mai 50100, Thailand

* Correspondence: drneaw@gmail.com

Simple Summary: The commercial canine ehrlichiosis vaccine is still not available. A limitation of developing vaccines is the knowledge of the humoral immune response against E. canis infection is still unknown. In this study, we designed the peptide vaccine candidate, namely GP194-43, for inducing hyperimmune serum in rabbits. The rabbit sera were used to examine for E. canis infective inhibition in macrophage-like cells (DH82). A decrease in E. canis infection $(<50 \%$ of infection) was observed on DH82 cells in the treated group with GP194-43 antiserum on the third day of the post-infection period. Cytokine genes in DH82 with/without rabbit sera were investigated and showed marked up-regulation of the IFNG expression level in DH82 cells in the treated group with GP19 $4-43$ antiserum. This study provides the preliminary information of immune response against E. canis of immunized animals and directions for genomic or/and proteomic studies involved in phagocyte-cell mediated immune response.

Abstract: In terms of its veterinary importance, vaccine development against Ehrlichia canis is needed. However, the effect of developing vaccines on humoral immune response against $E$. canis infection is still unknown. Novel GP19 4 -43 was synthesized according to E. canis GP19 epitope prediction. To restrict any loss and/or illness in the host animal, rabbits were used in this study to produce GP19 $4-43$ hyperimmune sera. The effect of GP19 $4-43$ hyperimmune sera on neutralization was examined in vitro by determining the inhibition of E. canis infection of the macrophage-like cell line (DH82) in the presence of the sera. Four groups of DH82 cells received differing treatments. These included E. canis experimentally infected DH82 cells, E. canis-infected DH82 cells with control rabbit serum (untreated group), E. canis-infected DH82 cells with GP19 $4-43$ rabbit antiserum (treated group) and uninfected cells (negative control group), respectively. The treated group developed a decrease $(p<0.01)$ in the percentage of $E$. canis infected cells after 3 days post-infection at $48.57 \pm 1$.28. In addition, real-time PCR analyses of cytokine mRNA expression involved with the macrophage, humoral, and cellular immune responses were conducted. The findings revealed an upregulated expression of IFNG in the treated group during the infection. This study demonstrated neutralization in the GP194-43 peptide hyperimmune sera of immunized rabbits. Notably, IFN- $\gamma$ production could be effectively promoted in canine macrophages in relation to the activation of macrophages and adaptive immune responses. The results of this study indicate the potential for the use of this immunogen in further investigations involving immunized and infected dogs as E. canis host species. 
Keywords: Ehrlichia canis; cytokine; DH82; GP19; hyperimmune; macrophage-like cells; peptide

\section{Introduction}

Canine monocytotropic ehrlichiosis (CME) is an important infectious disease occurring in dogs. It is commonly transmitted by the brown dog tick, Rhipicephalus sanguineus [1,2]. The etiological agent of this disease is Ehrlichia canis, a small, gram-negative, obligatory intracellular bacterium in the family Anaplasmataceae [3]. The agent invades and propagates in monocytes and macrophages, which can then lead to a variety of hematological and clinical signs [4,5]. The acute phases of CME are characterized by high fever, depression, anorexia, lymphadenomegaly, and splenomegaly, as well as clinical signs that include dermal petechiae, ecchymosis, and epistaxis [6]. Thrombocytopenia is the most prominent hematological change that occurs in the acute phase [7]. The chronic phase is characterized by pancytopenia due to suppression or destruction of bone marrow [8]. The clinical signs in the chronic phase are similar to those of the acute phase but are associated with a greater degree of severity [6]. E. canis infections in dogs have been reported in North and South America, Europe, Africa, and Asia [9-13]. Additionally, there has been evidence of E. canis infections in humans in certain specific regions [14].

Vaccines for E. canis are needed; however, many obstacles have impeded their development including identification of ehrlichial antigens, an understanding of the relevant genetic and antigenic variabilities, and a lack of animal models that reflect the immune responses of the hosts [15]. Previous studies have shown that inactivated and attenuated vaccine candidates for CME were capable of provoking a humoral response, but only partial clinical protection was achieved in dogs challenged with the virulent strain $[16,17]$. The peptide vaccine is among a variety of modern vaccines that represent a potential strategy for the prevention and treatment of pathogenic diseases [18-20]. There are a number of noteworthy advantages associated with this vaccine relevant to its low cost, ease of synthesis, and inherent level of safety. All of these attributes are considered extremely attractive features [21]. In the case of Ehrlichia spp., recombinant P29 protein and P28-19 peptides have been developed and demonstrated an ability to protect against E. muris in mouse models $[18,22]$. Since there is no available vaccine against $E$. canis, evidence of the role of the humoral immune response in immunized dogs, compared with those that have been infected, is limited.

Ehrlichial antigenic proteins have been selected based on the degree of reactivity of the proteins with antibodies obtained from infected animals [23]. Major immunodominant E. canis antigens can be recognized early in the infection period as 19-, 37-, 75-, and 140-kDa proteins $[24,25]$. The 19-kDa protein has been identified as glycoprotein (GP19) and has revealed orthologs with variable-length PCR target proteins (VLPT) of E. chaffeensis [26]. E. canis GP19 consists of a serine/threonine/glutamate (STE)-rich patch at the aminoterminal that contains species-specific antibody epitopes that were strongly recognized by the serum collected from an E. canis-infected dog [26]. Additionally, GP19 was found to be one of the most conserved proteins (98.8-100\% identities) among the geographically dispersed E. canis strains [27-29]. Due to the fact that a high degree of conservation and immunoreactive ability is attributed to E. canis GP19, this antigen has been recognized as an interesting target for diagnostic and vaccine development.

In this study, the GP19 epitope of E. canis was predicted. Subsequently, the GP194-43 peptide was synthesized to produce hyperimmune serum to examine the capability of neutralization against $E$. canis infection in vitro. The canine macrophage-like cell line (DH82) that was isolated from a dog with histiocytic sarcoma was representative of permanent macrophage morphology and excellent phagocytic cells. Furthermore, this cell line has been reported for use in the successful culture and infection of E. canis [30,31].

In addition, cytokine mRNA expression levels involved with macrophage, humoral and cellular immune responses were evaluated. Different types of cytokines have been 
discovered including interferons (IFN), interleukins (IL), and the tumor necrosis factor (TNF) [32,33]. Expression of the cytokine subunit genes, particularly IFN- $\gamma$ (IFNG), IL4 (IL4), IL-10 (IL10), IL-12 subunit beta (IL12B), IL-13 (IL13), and TNF (TNF), were investigated in this study to gain a greater understanding of the immunomodulatory action of the GP19 $4-43$ antiserum against $E$. canis infection.

\section{Materials and Methods}

\subsection{Construction of GP19 4 4-43 Peptide}

E. canis GP19 epitope sequences were determined based on protein conformation flexibility, hydrophilicity, and protein conformation. The prediction of the GP19 epitope containing the region was performed using Antibody Epitope Prediction-IEDB Analysis Resource (http:/ / tools.immuneepitope.org/bcell/, accessed on 12 April 2020). A 40-aminoacid epitope sequence at the N-terminal region containing the STE-rich patch of E. canis GP19 was selected and then labeled as the GP19 ${ }_{4-43}$ peptide. The 3D structure of the GP194-43 peptide was predicted using Phyre2 protein modeling, prediction, and analysis [34] (Figure S1). The GP194-43 peptide sequence was synthesized (Bio-Synthesis, Inc., Lewisville, TX, USA), resuspended in molecular biology grade water $(0.8 \mathrm{mg} / \mathrm{mL})$, and then kept at $-20^{\circ} \mathrm{C}$ until being used in the process going forward.

\subsection{Production of Rabbit Antiserum against $G P 19_{4-43}$}

Rabbit GP19 ${ }_{4-43}$ antiserum was generated against the GP19 $4-43$ peptide. New Zealand white rabbits were divided into 2 groups based on relevant immunogen formulations $(n=2$ rabbits each group). The first group was comprised of two rabbits that were immunized with $100 \mu \mathrm{g}$ of the GP19 $4-43$ peptide $/ 500 \mu \mathrm{L}$ with an equal volume of Montanide (SEPPIC, Paris, France). The rabbits in the second group received only $500 \mu \mathrm{L}$ of Montanide (control serum group). The immunized rabbits were intramuscularly administered 4 times at 2-week intervals. All rabbits were observed for clinical signs and behavioral changes that may have occurred at the pre- and post-immunization stages. These animal experiments were approved by the Animal Care and Use Committee (ACUC), approval No. S27/2560.

\subsection{Evaluation of Rabbit Antibody against GP19 4 -43 Using ELISA}

An indirect enzyme-linked immunosorbent assay (ELISA) was performed to monitor the specific rabbit sera IgG against the GP19 $9_{4-43}$ peptide of $E$. canis. Briefly, 96-well immunoplates (Nunc-Immuno Plate MaxiSorp, Intermed, Roskilde, Denmark) were coated with the synthetic GP19 $9_{4-43}$ peptide $\left(1 \mathrm{ng} /\right.$ well) and then incubated overnight at $4{ }^{\circ} \mathrm{C}$. The plates were washed three times with phosphate buffer saline (PBS) containing $0.05 \%$ Tween-20 (PBST) and then blocked with blocking buffer (5\% skim milk in PBS) for $1 \mathrm{~h}$. A volume of $100 \mu \mathrm{L}$ of GP19 $9_{4-43}$ immunized and control rabbit sera were added to each well; they were then incubated at $37^{\circ} \mathrm{C}$ for $1 \mathrm{~h}$. The plates were developed with secondary goat anti-rabbit IgG horseradish peroxidase (HRP) conjugated antibody (Dako Cytomation, Glostrup, Denmark) and incubated at $37^{\circ} \mathrm{C}$ for $1 \mathrm{~h}$. Subsequently, the 3,3',5,5'-tetramethylbenzidine (TMB) substrate (SeraCare Life Sciences, Gaithersburg, MD, USA) was added to each well, and they were then incubated at room temperature for 15 min away from light. The reaction was stopped by adding $50 \mu \mathrm{L}$ of $2 \mathrm{~N} \mathrm{H}_{2} \mathrm{SO}_{4}$. Optical density (OD) was measured spectrophotometrically at $450 \mathrm{~nm}$ using an Accu Reader Microplate reader M965 (Metertech, Taipei, Taiwan R.O.C.). The cut-off value was determined following the formula employed in the previous study; cut-off value $=$ mean negative control +3 standard deviations (SD) [35].

Rabbits were euthanized to collect blood samples one week after the last round of immunizations according to the AVMA Guidelines for the Euthanasia of Animals: 2020 Edition [36]. Blood samples were centrifuged to separate the sera and the pooled rabbit sera from each group were then stored at $-20{ }^{\circ} \mathrm{C}$ until being used. 


\subsection{Canine Macrophage-Like Cell Lines and Culture Conditions}

Canine macrophage-like cells (DH82, ATCC ${ }^{\circledR}$ CRL-10389 ${ }^{\mathrm{TM}}$ ) were maintained in Dulbecco's Modified Eagle Medium (DMEM; Gibco, Thermo Fisher Scientific, Waltham, MA, USA) that had been supplemented with $10 \%$ heat-inactivated fetal bovine serum (FBS; Gibco, Thermo Fisher Scientific, Waltham, MA, USA) in $25-\mathrm{cm}^{2}$ tissue culture flasks at $37^{\circ} \mathrm{C}$ and $5 \% \mathrm{CO}_{2}$ in a humidified incubator. Five milliliters) in $25-\mathrm{cm}^{2}$ tissue culture flasks at $37^{\circ} \mathrm{C}$ and $5 \% \mathrm{CO}_{2}$ in a humidified incubator. Five milliliters of cell-culture media were changed every 3-4 days. The cells were subcultured when about $90 \%$ confluence was reached; they were then observed under an inverted microscope (CK40; OLYMPUS, Olympus Optical, Tokyo, Japan). Cell detachment was performed using 1 milliliter of $0.25 \%$ Trypsin-EDTA, phenol red, 1X (Gibco, Thermo Fisher Scientific).

\subsection{E. canis Culture and Stock Conditions}

E. canis BF W053712X + 5 (PTA-5811 ${ }^{\mathrm{TM}}$, ATCC ${ }^{\circledR}$, Manassas, VA, USA) was used in this study and cultured in the 4th passage of DH82 according to the method employed in previous studies [4,37]. The monitoring of E. canis growth was performed at 1-week intervals by Giemsa staining via microscopic examination. Cells were propagated continuously until a level of $80 \%$ of infected cells was reached. Bacterial collection was performed manually by applying the previously described method [4]. Briefly, the approximate number of $5 \times 10^{6}$ DH82 cells that were infected with E. canis were detached using $1 \mathrm{~mL}$ of $0.25 \%$ Trypsin-EDTA; they were then incubated for $15 \mathrm{~min}$ at $37^{\circ} \mathrm{C}$. An equal volume of DMEM was added to the flask and the cell suspension was passed 10 times through a bent $26 \mathrm{G}$ needle to rupture the DH82 cells and release the intracellular bacteria mechanically. The suspension was centrifuged for $5 \mathrm{~min}$ at $1500 \times \mathrm{g}$. The supernatant containing cell-free bacteria was collected and the total volume was then adjusted to approximately $1 \mathrm{~mL}$ per $1 \times 10^{6}$ cell-free Ehrlichia. The cell-free Ehrlichia was used in invasive detection and cytokine gene investigation in the next process. A total of $1 \mathrm{~mL}$ of the $1 \times 10^{6}$ E. canis-infected DH82 cells were collected in 2-mL cryopreserved tubes with $5 \%$ dimethyl sulfoxide (DMSO) in DMEM and were then frozen at $-80^{\circ} \mathrm{C}$ until being used.

\subsection{Infective Inhibition of Ehrlichia canis in DH82 Cell Line}

\subsubsection{Infective Detection Using Light Microscopy}

Detection of infective inhibition using light microscopy was modified from the method that had been previously described [38]. Briefly, DH82 cell viability and number were checked with $0.4 \%$ Trypan Blue. The approximate proportion of viable cells based on cytospin was found to be over $95 \%$. The number of DH82 cells was adjusted to $1 \times 10^{5}$ cells $/ \mathrm{mL}$ and the cells were then deposited into $33 \mathrm{~mm}$ corning ${ }^{\circledR}$ culture dishes (Corning Inc., Corning, NY, USA) and fixed with $22 \times 22 \mathrm{~mm}$ coverslips. The cells were placed at the bottom of the wells and they were then incubated at $37^{\circ} \mathrm{C}$ and $5 \% \mathrm{CO}_{2}$ for $24 \mathrm{~h}$ to achieve cell adhesion. The dishes were then washed 3 times with $2 \mathrm{~mL}$ sterile $1 \times$ PBS (pH 7.4) and used for E. canis invasive detection.

The treatment group was divided into 4 groups according to the different treatments. These different treatment groups included E. canis-infected DH82 cells (positive control group), E. canis-infected DH82 cells with control serum (untreated group), E. canis-infected DH82 cells with GP19 4 -43 antiserum (treated group), and uninfected DH82 cells (negative control group), respectively. A volume of $100 \mu \mathrm{L}$ of $1 \times 10^{5}$ cell-free Ehrlichia was added to $400 \mu \mathrm{L}$ of the cell media (positive control group), $400 \mu \mathrm{L}$ of control serum (untreated group), and GP19 19 -43 antiserum (treated group). The specimens were then incubated at $37{ }^{\circ} \mathrm{C}$ and $5 \% \mathrm{CO}_{2}$ for $1 \mathrm{~h}$. Then, the suspension was added to the monolayer of DH82 cells that were adjusted to $1 \times 10^{5}$ cells in the dishes, and they were incubated at $37{ }^{\circ} \mathrm{C}$ and $5 \% \mathrm{CO}_{2}$ for $24 \mathrm{~h}$. Additionally, $1 \times$ PBS solution was used as a negative control (uninfected DH82 cells). After $24 \mathrm{~h}$, non-adherent bacteria were removed by washing the specimens twice with $2 \mathrm{~mL}$ of sterile $1 \times$ PBS solution. After being washed, the coverslips were fixed in $4 \%$ formaldehyde solution and stained with Diff-Quik staining 
(Sigma-Aldrich, St. Louis, MO, USA). The experiments were performed in duplicate for each group. The coverslips were then observed under a light microscope.

\subsubsection{Infective Detection Using an Immunocytochemistry (ICC) Technique}

The detection of $E$. canis infected cells was achieved following the ICC method applied in the previous study [39]. The number of DH82 cells were adjusted to $1 \times 10^{5}$ cells per ml. Furthermore, $1 \times 10^{4} \mathrm{DH} 82$ cells in $100 \mu \mathrm{L}$ cell culture media were cultured in duplicated 96-well plates for $24 \mathrm{~h}$ in a humidified incubator at $37{ }^{\circ} \mathrm{C}$ and $5 \% \mathrm{CO}_{2}$ to allow for cell adhesion. The wells were then washed 3 times with $100 \mu \mathrm{L}$ PBS/0.1\% Tween-20 (PBST; $\mathrm{pH}$ 7.4) and used for invasive detection.

The treatment group was divided into 4 groups as has been mentioned above. For the positive control, and the untreated and treated groups, $100 \mu \mathrm{L}$ of $5 \times 10^{4}$ cell-free Ehrlichia was added to $200 \mu \mathrm{L}$ of cell media, $200 \mu \mathrm{L}$ of control serum, and GP19 $9_{4-43}$ antiserum, respectively. The specimens were then incubated at $37^{\circ} \mathrm{C}$ for $1 \mathrm{~h}$. In the negative control group, PBS solution was used instead of Ehrlichia. Additionally, $100 \mu \mathrm{L}\left(1 \times 10^{4}\right.$ cellfree Ehrlichia) of the suspension was added to the monolayer of DH82 cells in the media and incubated at $37{ }^{\circ} \mathrm{C}$ with $5 \% \mathrm{CO}_{2}$ for 1 or 3 days. The media were then discarded, and non-adherent bacteria were removed by washing the bacteria three times with $100 \mu \mathrm{L}$ of PBST. The cells were fixed with cold $4 \%$ paraformaldehyde for $15 \mathrm{~min}$. Endogenous peroxidase was blocked using $3 \% \mathrm{H}_{2} \mathrm{O}_{2}$ in $1 \times$ PBS for 10-30 min. The cells were then blocked with $3 \%$ bovine serum albumin (BSA; AMRESCO, Solon, OH, USA) and washed three times with PBST. A solution comprised of 1:200 dilution of the primary antibody (rabbit GP19 $4_{4-43}$ antiserum) was added to the plates and they were incubated at $4{ }^{\circ} \mathrm{C}$ overnight. The specimens were then washed once with PBST and incubated in a solution of 1:400 dilution of horseradish peroxidase (HRP)-conjugated goat anti-rabbit IgG (SigmaAldrich) for $1 \mathrm{~h}$ at RT. The plates were washed three times with PBST and then $75 \mu \mathrm{L}$ of stable DAB was added (Invitrogen ${ }^{\mathrm{TM}}$, Carlsbad, CA, USA) for 2-5 min before being rinsed with tap water. The results were observed under an inverted microscope (400X, CK40; OLYMPUS, Shinjuku City, Tokyo, Japan) and infected cells were stained reddish-brown. A semi-quantitative scoring system for the stained cells was adopted from the system that had been previously described [40]. The average percentage of E. canis infected cells that were stained reddish-brown using the ICC technique was determined manually in 3 random fields and were then scored as follows; $0=$ negative, $1=10 \%$ of the cells with positive staining, $2=$ between $10-50 \%$ of the cells with positive staining, $3=$ more than $50 \%$ of the cells with positive staining.

\subsection{Cytokine Gene Expression Profiles}

To investigate the effects of the GP19 $9_{4-43}$ peptide on cytokine expression, a volume of $100 \mu \mathrm{L}$ of $1 \times 10^{5}$ cell-free Ehrlichia was added to $400 \mu \mathrm{L}$ of the cell media (positive control group), control serum (untreated group), or GP19 $4-43$ antiserum (treated group). The specimens were then incubated at $37^{\circ} \mathrm{C}$ and $5 \% \mathrm{CO}_{2}$ for $1 \mathrm{~h}$. The suspension was added to the monolayer of $1 \times 10^{6} \mathrm{DH} 82$ cells in duplicate 24-well plates. In the negative control group, PBS solution was used instead of Ehrlichia. Plates were incubated at $37^{\circ} \mathrm{C}, 5 \% \mathrm{CO}_{2}$ for 1 or 3 days. After incubation, samples from each well were combined to achieve a cell density of $1 \times 10^{6}$ cells. RNAlater ${ }^{\circledR}$ solution was then added to the cells to preserve total RNA. RNA extraction was performed using a Total RNA Extraction Kit (RBCBioscience, Taipei, Taiwan) following the manufacturer's instructions. RNA yields and concentrations were measured using a DU 730 nanoVette UV/Vis Spectrophotometer (Beckman Coulter, Brea, CA, USA). For cDNA synthesis, $2 \mu \mathrm{g}$ of total RNA were used as a starter in $20 \mu \mathrm{L}$ of a reaction mixture containing $2 \mu \mathrm{M}$ Random Hexamer, $2.5 \mathrm{mM}$ deoxynucleotide triphosphates (dNTPs), $5 \times$ RT buffer, 40 U RNase inhibitor (Invitrogen ${ }^{\mathrm{TM}}$, Carlsbad, CA, USA), RNase-free water and $200 \mathrm{U}_{\text {Bioscript }}{ }^{\mathrm{TM}}$ reverse transcriptase (Bioline, Memphis, TN, USA). The cDNA synthetic reaction was carried out in a T100 ${ }^{\mathrm{TM}}$ thermal cycler (Bio-Rad Laboratories, Hercules, CA, USA) according to the manufacturer's instructions. 
Approximately $50 \mathrm{ng}$ of the cDNA samples were quantitatively analyzed for the mRNA transcription of gene coding that involved interferon-gamma (IFNG), interleukin 4 (IL4), interleukin 10 (IL10), interleukin 12B (IL12B), interleukin 13 (IL13), and tumor necrosis factor-alpha (TNF), while the glyceraldehyde 3-phosphate dehydrogenase (GAPDH) was used as a reference gene. Real-time RT-PCR was performed using a SensiFAST SYBR Hi-ROX Kit (Bioline, London, UK) following the protocol described by the manufacturer and by using CFX96 Touch $^{\mathrm{TM}}$ Real-Time PCR (Bio-Rad, Hercules, CA, USA). Specific information regarding primer pairs used in this study is presented in Table S1. Sequences of the primers were designed by Primer3plus; primer synthesis was performed by Integrated DNA Technologies (IDT; Coralville, IA, USA). After gradient-PCR, the real-time RT-PCR cycling conditions were applied according to the initial denaturation at $94{ }^{\circ} \mathrm{C}$ for $5 \mathrm{~min}$ followed by 40 cycles at $94{ }^{\circ} \mathrm{C}$ for $30 \mathrm{~s}, 59^{\circ} \mathrm{C}$ for $10 \mathrm{~s}$ and $72{ }^{\circ} \mathrm{C}$ for $20 \mathrm{~s}$, ending with a final extension at $72{ }^{\circ} \mathrm{C}$ for $5 \mathrm{~min}$ for all genes. After completion of the assessment of the real-time RT-PCR cycles, dissociation curves were analyzed to confirm that the PCR product obtained by real-time RT-PCR included the correct components. The specificity of real-time RT-PCR on the specified genes was confirmed by $2 \%$ agarose gel electrophoresis. Analysis of relative gene expression was calculated from the $\mathrm{Ct}$ of the target gene and the reference gene (GAPDH). The expression levels (fold-difference) were reported using the $2^{-\Delta \Delta \mathrm{Ct}}$ method [41].

\subsection{Data Analysis}

The data from all three experiments were combined and analyzed to identify any outliers using the robust regression and outlier removal (ROUT) method. The normality test was completed using the Shapiro-Wilk test prior to performing statistical analysis. Statistical analyses were performed using one-way ANOVA or multiple t-tests that employed GraphPad Prism 8.2.0 (GraphPad Software, Inc., San Diego, CA, USA). Results of the statistical analyses were considered significant in all experiments when $p<0.05$. Multiple comparisons of each pair were made using the Holm-Sidak method. Results were reported as mean plus standard error (SE). The cytokine genes obtained from differential expression data were used to create a network of genes using CytoScape with a GeneMANIA plugin [42].

\section{Results}

\subsection{Rabbit Antibody Response to GP19 4 -43 Peptide}

All immunized and non-immunized rabbits displayed no clinical signs and behavioral changes at the pre- and post-immunization stages. The OD values of the immunized and control rabbit sera are shown in Figure 1. Following immunization of the rabbits, two peaks of antibody levels against the GP19 $9_{4-43}$ peptide were detected 14 days after the first immunization and 7 days after the third immunization. The average OD values and SD of immunized rabbit sera weekly recorded at $0.240 \pm 0.025,1.661 \pm 0.065,2.037 \pm 0.012$, $1.960 \pm 0.013,1.885 \pm 0.005,2.202 \pm 0.010,1.982 \pm 0.043$ and $2.191 \pm 0.022$, respectively. The average OD values and SD of non-immunized control rabbit sera were 0.271 and 0.038 , respectively. Thus, the cut-off point of the indirect ELISA detecting rabbit antibody against GP19 $14-43$ of E. canis was 0.385 .

\subsection{Infective Inhibition of E. canis to DH82 Cell Line}

\subsubsection{Positive E. canis Infection Detected by Light Microscopy}

With the exception of the negative control group, E. canis cells infected with microorganisms within the membrane-bound compartments (morulae) were observed in the DH82 cytoplasm under light microscopy. This was attributed to a heavy degree of infection $\left(1 \times 10^{5}\right.$ cell-free Ehrlichia $)$ on day 1 of the post-infection period. 


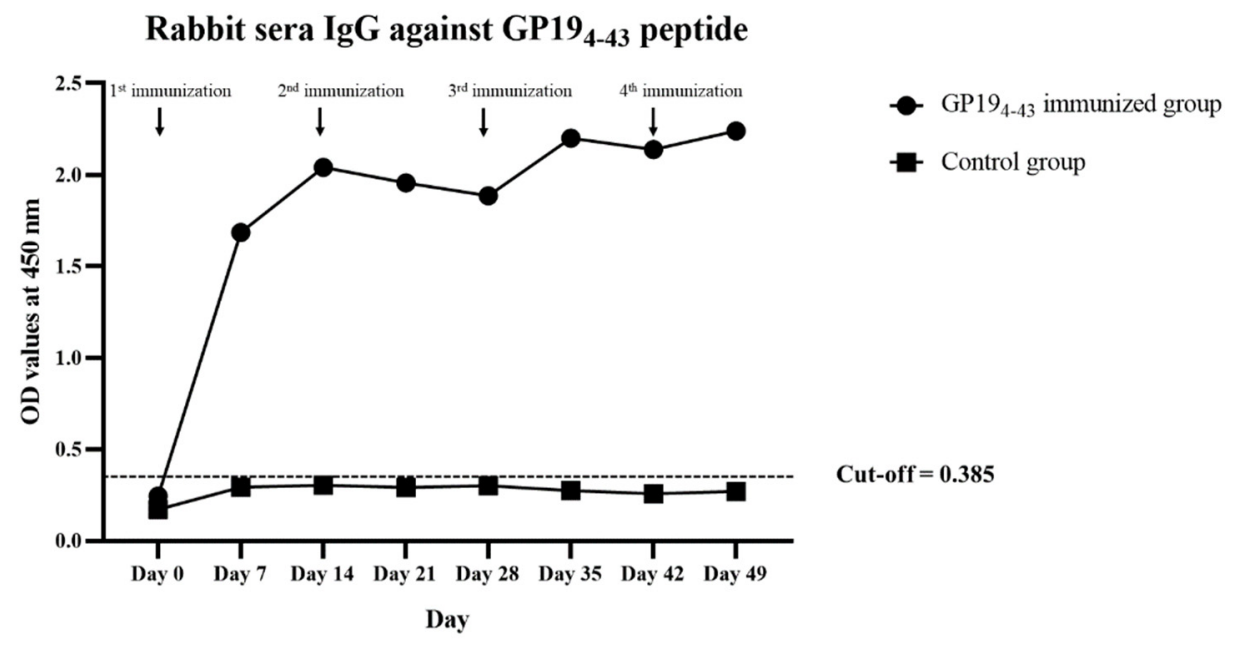

Figure 1. Antibody titer levels measured by indirect ELISA against GP19 $4-43$ peptide nonimmunization (control group) and immunization in rabbits throughout the experimental period.

\subsubsection{E. canis Infective Inhibition Detected by ICC Technique}

With the exception of the negative control, infection of E. canis was graded with a score number of 3 ( $>50 \%$ positive cells) in all groups on day 1 of the post-infection period (Figure 2A). The percentages of E. canis infected cells in the positive control, and the treated and untreated groups, were $90.925 \pm 1.178,90.065 \pm 2.772$, and $92.918 \pm 1.459$, respectively (Figure 2B).

Notably, stimulated DH82 indicated different percentages of E. canis infected cells on the third day of the post-infection period ( $p<0.01$, Figure 2B). Furthermore, the treated group revealed lower percentages of positive staining cells with DAB staining (10-50\% positive infected cells; score number 2 . The percentages of $E$. canis infected cells in the positive control, treated and untreated groups were $92.291 \pm 2.269,48.573 \pm 1.282$, and $90.967 \pm 3.132$.

\subsection{Relevance of GP194-43 Antiserum on Cytokine Gene Expression}

Gene expression levels in the E. canis-infected group revealed overall down-regulation among cytokine genes IFNG, IL10, IL12B, and IL13 (Figure 3). In contrast, IL4 displayed a degree of upregulation $(p<0.01)$ when in the E. canis-infected group compared with all groups throughout the post-infection phase of the experiment (Figure 3B).

IFNG gene expression was maintained following E. canis infection in the presence of GP19 4 -43 antiserum with a degree of up-regulation of IFNG on day $3(p<0.001)$ when compared with uninfected and E. canis-infected group, likewise compared with E. canis infection in the control serum $(p<0.01)$ (Figure 3A). IL13 gene expression in the treated group revealed significantly downregulated levels of expression when compared to the uninfected group throughout the experiment $(p<0.01)$ (Figure 3E). The levels of gene expression of the other cytokine genes involved with the helper Th response (IL4, IL10, and IL12B) and the pro-inflammatory cytokine gene (TNF gene) in the treated group revealed no significant differences in the expression levels when compared to the uninfected group (Figure 3). 
A

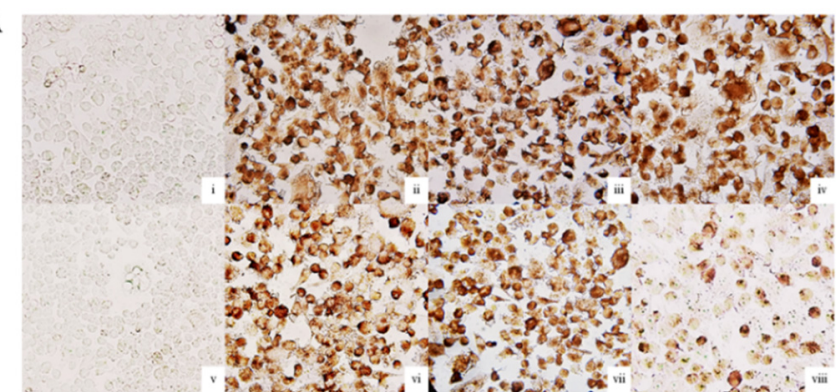

B

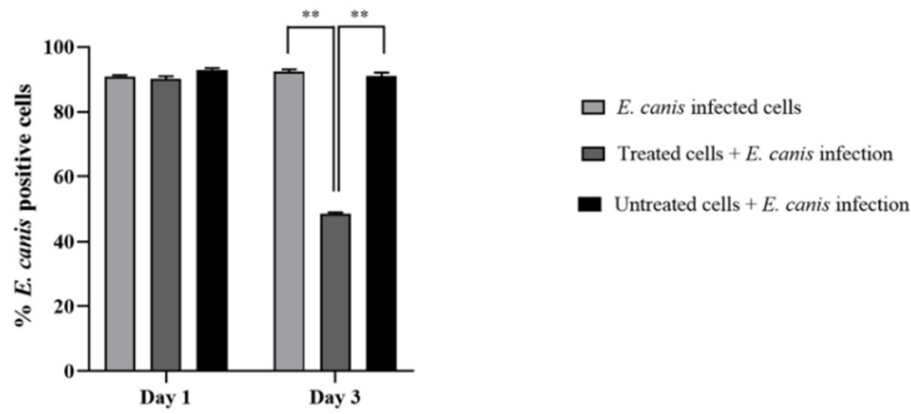

Figure 2. E. canis infective results in macrophage-like cells (DH82) using immunocytochemistry (ICC). (A) Representative micrographs of E. canis infective cells stained with DAB to indicate positive cells under an inverted microscope (400×, CK40; OLYMPUS): (i-iv) E. canis infective detection on day 1 post-infection in uninfected cells, E. canis infected cells, E. canis-infected cells with control serum (untreated group) and E. canis-infected DH82 cells with GP194-43 antiserum (treated group), respectively; (v-viii) E. canis infective detection on day 3 post-infection in uninfected cells, E. canis infected cells, E. canis-infected cells with control serum (untreated group) and E. canis-infected DH82 cells with GP19-43 antiserum (treated group), respectively. (B) Bar graphs represent the percentage of E. canis-infected cells on day 1 and day 3 post-infection in E. canis infected cells, E. canis-infected cells with control serum (untreated group) and E. canis-infected DH82 cells with GP19 ${ }_{4-43}$ antiserum (treated group), respectively. Data are represented as mean $\pm \mathrm{SE}$, one-way ANOVA, ${ }^{* *} p<0.01$.
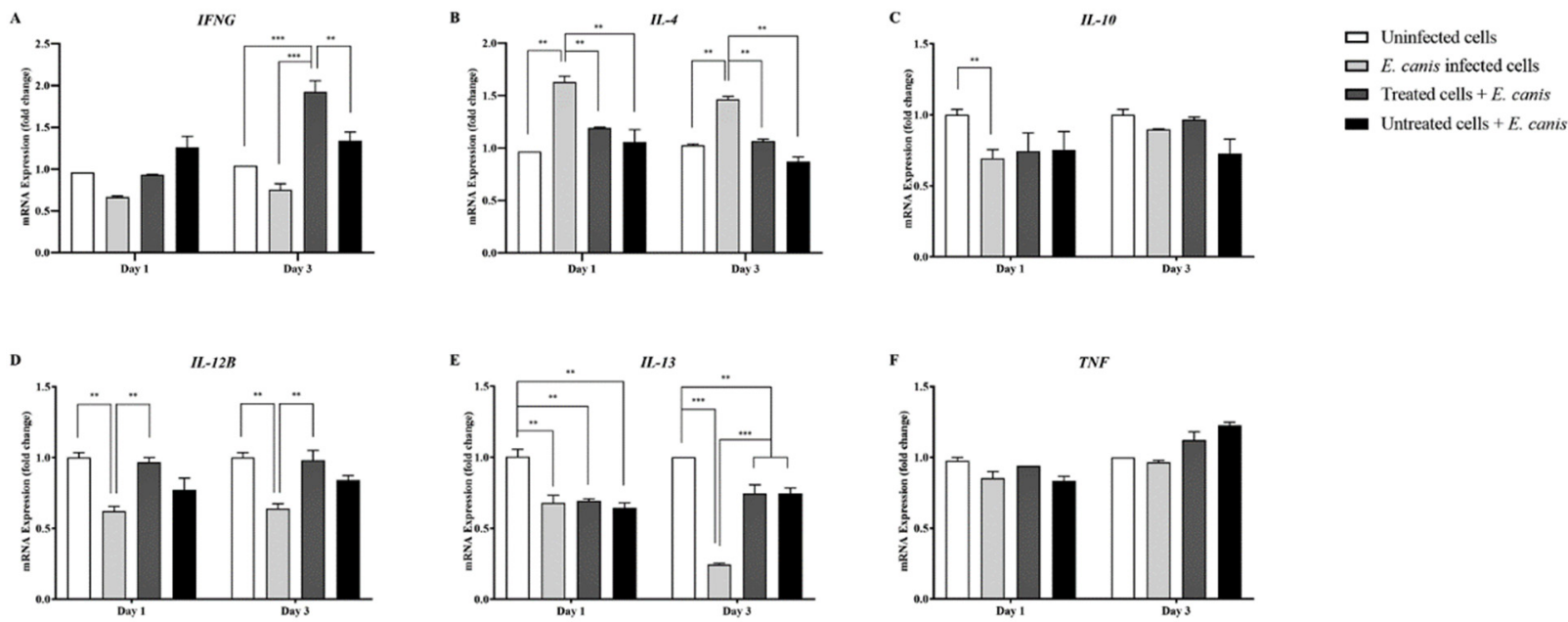

Figure 3. Real-time RT-PCR analyses of the canine macrophage-like cell line (DH82) mRNA expression involved in cytokine activity. Bar graphs showing relative (A) IFNG, (B) IL4, (C) IL10, (D) IL12B, (E) IL13, and (F) TNF mRNA expression levels after normalization to the GAPDH gene in uninfected cells, E. canis infected cells, E. canis-infected DH82 cells with GP194-43 antiserum (treated group) and E. canis-infected cells with control serum (untreated group), respectively. Data is represented as mean $\pm \mathrm{SE}\left(n=4\right.$ each treatment), one-way ANOVA or multiple $t$-test, ${ }^{* *} p<0.01{ }^{* * *} p<0.001$. 


\section{Discussion}

Despite the importance of veterinary medicine and the possibility of zoonotic pathogens affecting humans, very few studies have been conducted on vaccine development against E. canis infection. GP194-43 peptide serves as an immunogen in that it mimics the antigen structure, GP19 of E. canis, which can then elicit the antibody of infected dogs within 14 days. This model was constructed and used to produce rabbit GP194-43 antiserum in the present study [21,43]. Additional immunizations (two-week intervals) were given to raise the concentration of the antibodies. After the 3rd round of immunizations, immunized rabbit antibody titers had risen to a peak within a week of the post-immunization period. Rabbit GP19 $9_{4-43}$ antiserum containing a specific antibody was used to determine the effects of the GP19 ${ }_{4-43}$ antiserum to macrophages against $E$. canis infection in the canine macrophage. The 4th passages of DH82 cells were representative of canine macrophage-like cells that could be used to control relevant cell characteristics, including cell infection and gene expression [30,44].

As was the case in previous studies, the passive transfer of serum containing Ehrlichiaspecific immunoglobulin $\mathrm{G}(\mathrm{IgG})$ to E. chaffeensis-infected SCID mice pre- and post-infection displayed an effective degree of elimination of Ehrlichia $[45,46]$. Our present study reinforced the role of GP19 $9_{4-43}$ antiserum against $E$. canis and showed the effects of elimination of Ehrlichia in canine macrophages on the third day of the post-infection period. Results of the current experiment suggest the possible importance of the following mechanism. Macrophages could be triggered by GP19 ${ }_{4-43}$ antiserum with regard to the neutralizing activity against $E$. canis infection by a decrease in the number of positive infected cells by the third day of the post-infection period. Since this study focused on the early infection of E. canis, the effects of inhibition of E. canis infection of the macrophage-like cell line (DH82) in the presence of the antisera are still unknown in the context of long-term infection. Further studies on the neutralization role of the antibody against GP19 immunogens and E. canis infection, and between early and long-term infection, are needed to understand the effect of vaccine candidates against $E$. canis infection.

The expression of cytokine genes involved in macrophage-adaptive immune responses in DH82 cells was unraveled in this study. With the absence of GP19 $9_{4-43}$ antiserum, the E. canis infected DH82 cells revealed significantly downregulated levels of expression of IFNG and IL12B genes that involved with macrophage-Th1 cells. These results were consistent with the findings of a previous study that had reported a low level of detection of IL-12p70 and IL-12p40 in mice spleen during virulent IOE lethal infection [47]. Contrastingly, the IFNG expression of E. canis infected cells in the presence of the GP194-43 antiserum (treated group) displayed significantly up-regulated levels on day 3 when compared to all groups (Figure 3A). A decrease in E. canis infection was also observed on the third day of the post-treatment period; accordingly, the IFNG expression in the treated cell group could be related to the elimination of the intracellular microorganism, E. canis. Moreover, IFNG is the only cytokine gene investigated in this study that shows significantly different expression between the treated and untreated groups. The findings of the present study indicate the strong possibility that GP19 $9_{4-43}$ antiserum was able to promote IFN- $\gamma$ production in DH82 cells against $E$. canis infection. In addition, the outcomes of the present study support the use of IFN- $\gamma$ as an indicator of protective immunity in animals immunized with Ehrlichia immunogens, as was evident from the findings of the previous studies $[48,49]$.

The cytokine gene expression levels that were involved with macrophage-Th2 and B cells, including IL4, IL10, and IL13 genes in DH82 cells, were also investigated. The results displayed no difference of these genes in uninfected cells, E. canis infected DH82 with and without GP19 ${ }_{4-43}$ antiserum. Notable, the E. canis infected DH82 cells revealed upregulated levels of expression of IL4 which reported a negative relationship with IFNG expression. With regard to vaccine development against Ehrlichia spp., the previous study revealed that the killed vaccine of E. ruminantium elicited both CD4+ and CD8+ subsets to produce IFN- $\gamma$ in the absence of IL4, indicating a type 1 response [50]. However, the relation 
of these two genes has not been reported in canine macrophages. Investigation of the macrophage-adaptive immune response in animals immunized with the GP19 ${ }_{4-43}$ peptide is further needed for a clearer understanding of the protective ability.

The overproduction of IL-10 and TNF- $\alpha$ was reported to be associated with toxic shocklike syndrome and mortality in animal models of fetal monocytic ehrlichiosis, according to the findings of previous studies [47,51-53]. In the present study, there were no significant differences in IL10 and TNF gene expression levels among E. canis infected cells (positive, treated, and the untreated group). Further studies are recommended on the expression of the anti-inflammatory and pro-inflammatory cytokine genes in various cells or animal models over a longer period of time to reach a definitive conclusion on the effects of the antiserum on these genes.

Data on the gene expression levels for both up- and down-regulation trends were used to analyze the network of relationships using GeneMANIA plug-ins [54]. The results revealed evidence of a relationship among query genes in this study (IFNG, IL4, IL10, IL12B, IL13, and TNF), as well as among the genes in the public dataset of functional association networks. Predictions of known gene co-expression and physical interactions in the cytokine activity pathway with query genes (brown nodes), leukocyte differentiation (blue nodes), leukocyte proliferation (lilac nodes), lymphocyte proliferation (violet nodes), and inflammatory responses (yellow nodes) were defined by the presence of additional genes that are related to the individual query genes (Figure 4 ). In addition, some genes were indirectly present in the network, namely CSF1, IL10RA, DGKA, IFNGR1, IFNGR2, IL21R, IL24, IL4R, and FLT3LG. Our analyses of the cytokine networks suggest the possible linkages of the cytokine genes identified in this study with additional cytokines involved in the E. canis infection responses with the collaboration of other macrophages and other immune cells. Therefore, cytokine detection in different immune cells, including macrophages, CD4+ and CD8+ T cells, observed in animal models would be needed to better understand the role of the GP194-43 peptide as an immunogen in the development of a vaccine against E. canis.

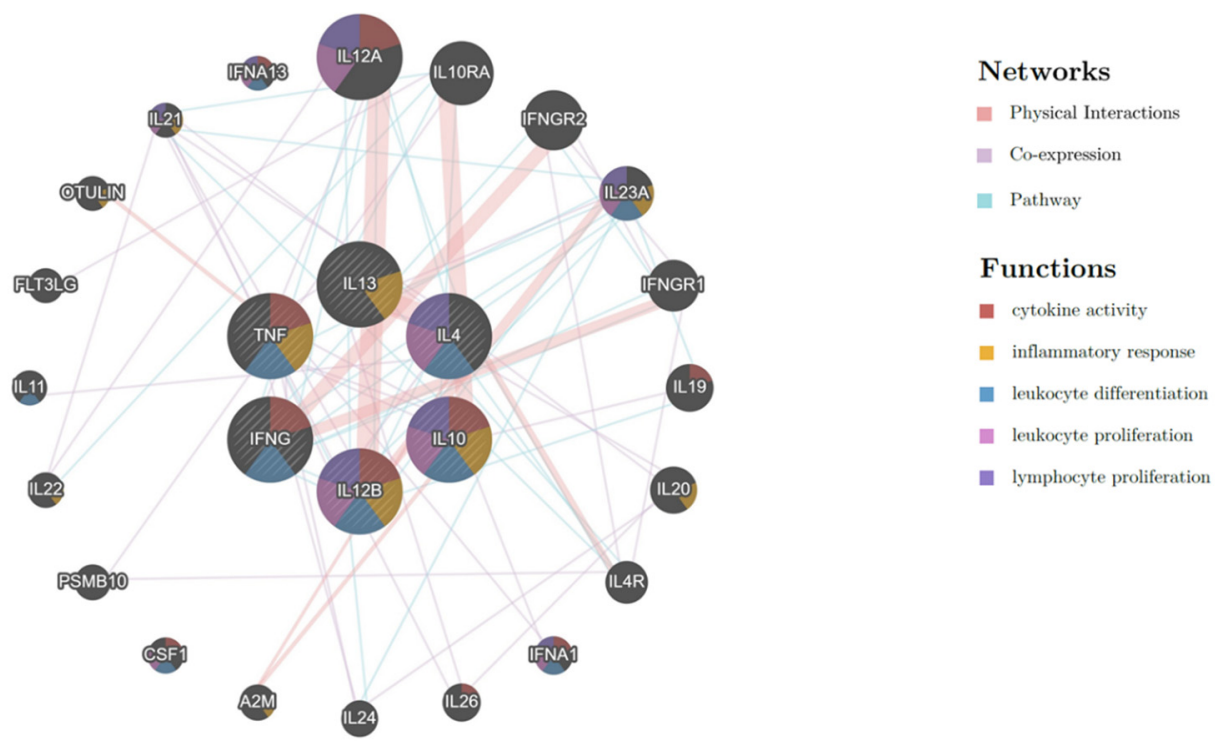

Figure 4. GeneMANIA Cytoscape interaction network of known physical interactions, gene coexpression, and cytokine pathway with query genes (IFNG, IL4, IL10, IL12B, IL13, and TNF) that were expressed in this study were found to be involved with the function of cytokine activity (brown nodes), inflammatory response (yellow nodes), leukocyte differentiation (blue nodes), leukocyte proliferation (lilac nodes) and lymphocyte proliferation (violet nodes). Additional genes are predicted to be involved in the network (gray nodes). 


\section{Conclusions}

Synthetic GP19 $9_{4-43}$ peptide was used as an immunogen to produce rabbit GP194-43 hyperimmune serum in the present study. The GP19 $9_{4-43}$ antiserum was examined for E. canis infective inhibition in macrophage-like cells (DH82). A decrease in ehrlichial infection was observed in the GP19 ${ }_{4-43}$ antiserum treated group when compared with the positive control and the untreated group on the third day of the post-infection period, as was observed through the use of the ICC method. Cytokine genes involved in macrophage-adaptive immune responses were also investigated. The present findings highlight the expression level of IFNG displaying marked up-regulation in the treated group. These findings can fill the existing gaps in terms of the recorded knowledge of immune response against $E$. canis infection in both treated and untreated macrophages with GP19 ${ }_{4-43}$ antiserum containing the specific antibody. This study also indicates potential directions for future studies on the genes involved in phagocyte-cell mediated immune response. Notably, the relative macrophage, humoral and cellular immune response in both in vitro and in vivo studies will be needed for further verification.

Supplementary Materials: The following are available online at https:/ / www.mdpi.com/article/ 10.3390/ani11082310/s1, Figure S1: Amino acid sequence of E. canis GP19 ${ }_{4-43}$ peptide, Table S1: PCR and oligonucleotide sequences of primers targeting cytokine genes used in this study.

Author Contributions: Conceptualization, B.N. and N.S.; validation, S.T. (Saruda Tiwananthagorn) and S.T. (Sahatchai Tangtrongsup); formal analysis, B.N.; investigation, B.N., A.R., A.M. and P.K.; resources, S.T. (Saruda Tiwananthagorn) and Y.-T.C.; data curation, B.N.; writing-original draft preparation, B.N.; writing-review and editing, B.N. and N.S.; visualization, B.N.; supervision, N.S., S.T. (Saruda Tiwananthagorn) and S.T. (Sahatchai Tangtrongsup); project administration, N.S. All authors have read and agreed to the published version of the manuscript.

Funding: This research was funded by Research and Researchers for Industries (RRi), Thailand Research Fund (TRF), grant No. PHD58I0063, and by the Centre of Excellence for Veterinary Bioscience, Chiang Mai University, grant No. 012/2562.

Institutional Review Board Statement: The animal experiment was approved by the Animal Care and Use Committee (ACUC) of Chiang Mai University, approval No. S27/2560.

Data Availability Statement: All data in this study have been included in the manuscript.

Acknowledgments: The authors would like to thank Veterinary Diagnostic Laboratory, Chiang Mai University for the facility of cell culture and immunocytochemistry experiment.

Conflicts of Interest: The authors declare no conflict of interest.

\section{References}

1. Bremer, W.G.; Schaefer, J.J.; Wagner, E.R.; Ewing, S.A.; Rikihisa, Y.; Needham, G.R.; Jittapalapong, S.; Moore, D.L.; Stich, R.W. Transstadial and intrastadial experimental transmission of Ehrlichia canis by male Rhipicephalus sanguineus. Vet. Parasitol. 2005, 131, 95-105. [CrossRef]

2. Fourie, J.J.; Stanneck, D.; Luus, H.G.; Beugnet, F.; Wijnveld, M.; Jongejan, F. Transmission of Ehrlichia canis by Rhipicephalus sanguineus ticks feeding on dogs and on artificial membranes. Vet. Parasitol. 2013, 197, 595-603. [CrossRef]

3. Dumler, J.S.; Barbet, A.F.; Bekker, C.P.; Dasch, G.A.; Palmer, G.H.; Ray, S.C.; Rikihisa, Y.; Rurangirwa, F.R. Reorganization of genera in the families Rickettsiaceae and Anaplasmataceae in the order Rickettsiales: Unification of some species of Ehrlichia with Anaplasma, Cowdria with Ehrlichia and Ehrlichia with Neorickettsia, descriptions of six new species combinations and designation of Ehrlichia equi and 'HGE agent' as subjective synonyms of Ehrlichia phagocytophila. Int. J. Syst. Evol. Microbiol. 2001, 51, 2145-2165. [CrossRef] [PubMed]

4. Ferrolho, J.; Simpson, J.; Hawes, P.; Zweygarth, E.; Bell-Sakyi, L. Growth of Ehrlichia canis, the causative agent of canine monocytic ehrlichiosis, in vector and non-vector ixodid tick cell lines. Ticks Tick. Borne. Dis. 2016, 7, 631-637. [CrossRef] [PubMed]

5. Zhang, J.; Popov, V.L.; Gao, S.; Walker, D.H.; Yu, X. The developmental cycle of Ehrlichia chaffeensis in vertebrate cells. Cell. Microbiol. 2007, 9, 610-618. [CrossRef] [PubMed]

6. Harrus, S.; Waner, T. Diagnosis of canine monocytotropic ehrlichiosis (Ehrlichia canis): An overview. Vet. J. 2011, 187, $292-296$. [CrossRef] [PubMed]

7. Waner, T.; Leykin, I.; Shinitsky, M.; Sharabani, E.; Buch, H.; Keysary, A.; Bark, H.; Harrus, S. Detection of platelet-bound antibodies in beagle dogs after artificial infection with Ehrlichia canis. Vet. Immunol. Immunopathol. 2000, 77, 145-150. [CrossRef] 
8. Mylonakis, M.E.; Koutinas, A.F.; Breitschwerdt, E.B.; Hegarty, B.C.; Billinis, C.D.; Leontides, L.S.; Kontos, V.S. Chronic canine ehrlichiosis (Ehrlichia canis): A retrospective study of 19 natural cases. J. Am. Anim. Hosp. Assoc. 2004, 40, 174-184. [CrossRef] [PubMed]

9. Aguiar, D.M.; Zhang, X.; Melo, A.L.T.; Pacheco, T.A.; Meneses, A.M.C.; Zanutto, M.S.; Horta, M.C.; Santarém, V.A.; Camargo, L.M.A.; McBride, J.W.; et al. Genetic diversity of Ehrlichia canis in Brazil. Vet. Microbiol. 2013, 164, 315-321. [CrossRef]

10. Aguirre, E.; Sainz, A.; Dunner, S.; Amusategui, I.; López, L.; Rodríguez-Franco, F.; Luaces, I.; Cortés, O.; Tesouro, M.A. First isolation and molecular characterization of Ehrlichia canis in Spain. Vet. Parasitol. 2004, 125, 365-372. [CrossRef] [PubMed]

11. Beall, M.J.; Alleman, A.R.; Breitschwerdt, E.B.; Cohn, L.A.; Couto, C.G.; Dryden, M.W.; Guptill, L.C.; Iazbik, C.; Kania, S.A.; Lathan, P.; et al. Seroprevalence of Ehrlichia canis, Ehrlichia chaffeensis and Ehrlichia ewingii in dogs in North America. Parasit. Vectors. 2012, 5, 1-11. [CrossRef] [PubMed]

12. Kamani, J.; Lee, C.-C.; Haruna, A.M.; Chung, P.-J.; Weka, P.R.; Chung, Y.-T. First detection and molecular characterization of Ehrlichia canis from dogs in Nigeria. Res. Vet. Sci. 2013, 94, 27-32. [CrossRef] [PubMed]

13. Nazari, M.; Lim, S.Y.; Watanabe, M.; Sharma, R.S.; Cheng, N.A.; Watanabe, M. Molecular detection of Ehrlichia canis in dogs in Malaysia. PLoS Negl. Trop. Dis. 2013, 7, e1982. [CrossRef]

14. Perez, M.; Bodor, M.; Zhang, C.; Xiong, Q.; Rikihisa, Y. Human infection with Ehrlichia canis accompanied by clinical signs in Venezuela. Ann. N. Y. Acad. Sci. 2006, 1078, 110-117. [CrossRef]

15. McBride, J.W.; Walker, D.H. Progress and obstacles in vaccine development for the ehrlichioses. Expert Rev. Vaccines 2010, 9, 1071-1082. [CrossRef] [PubMed]

16. Mahan, S.; Kelly, P.J.; Mahan, S.M. A preliminary study to evaluate the immune responses induced by immunization of dogs with inactivated Ehrlichia canis organisms. Onderstepoort J. Vet. Res. 2005, 72, 119-128. [CrossRef]

17. Rudoler, N.; Baneth, G.; Eyal, O.; van Straten, M.; Harrus, S. Evaluation of an attenuated strain of Ehrlichia canis as a vaccine for canine monocytic ehrlichiosis. Vaccine 2012, 31, 226-233. [CrossRef]

18. Thomas, S.; Thirumalapura, N.R.; Crocquet-Valdes, P.A.; Luxon, B.A.; Walker, D.H. Structure-based vaccines provide protection in a mouse model of ehrlichiosis. PLoS ONE 2011, 6, e27981. [CrossRef]

19. Dormitzer, P.R.; Ulmer, J.B.; Rappuoli, R. Structure-based antigen design: A strategy for next generation vaccines. Trends Biotechnol. 2008, 26, 659-667. [CrossRef]

20. Shams, H. Recent developments in veterinary vaccinology. Vet. J. 2005, 170, 289-299. [CrossRef]

21. Croft, N.P.; Purcell, A.W. Peptidomimetics: Modifying peptides in the pursuit of better vaccines. Expert Rev. Vaccines 2011, 10, 211-226. [CrossRef] [PubMed]

22. Thirumalapura, N.R.; Crocquet-Valdes, P.A.; Saito, T.B.; Thomas, S.; McBride, J.W.; Walker, D.H. Recombinant Ehrlichia P29 protein induces a protective immune response in a mouse model of ehrlichiosis. Vaccine 2013, 31, 5960-5967. [CrossRef] [PubMed]

23. Thomas, S. Development of structure-based vaccines for ehrlichiosis. Methods Mol. Biol. 2016, 1403, 519-534. [CrossRef]

24. Doyle, C.K.; Nethery, K.A.; Popov, V.L.; McBride, J.W. Differentially expressed and secreted major immunoreactive protein orthologs of Ehrlichia canis and E. chaffeensis elicit early antibody responses to epitopes on glycosylated tandem repeats. Infect. Immun. 2006, 74, 711-720. [CrossRef] [PubMed]

25. McBride, J.W.; Corstvet, R.E.; Gaunt, S.D.; Boudreaux, C.; Guedry, T.; Walker, D.H. Kinetics of antibody response to Ehrlichia canis immunoreactive proteins. Infect. Immun. 2003, 71, 2516-2524. [CrossRef] [PubMed]

26. McBride, J.W.; Doyle, C.K.; Zhang, X.; Cardenas, A.M.; Popov, V.L.; Nethery, K.A.; Woods, M.E. Identification of a glycosylated Ehrlichia canis 19-kilodalton major immunoreactive protein with a species-specific serine-rich glycopeptide epitope. Infect. Immun. 2007, 75, 74-82. [CrossRef]

27. Hsieh, Y.-C.; Lee, C.-C.; Tsang, C.-L.; Chung, Y.-T. Detection and characterization of four novel genotypes of Ehrlichia canis from dogs. Vet. Microbiol. 2010, 146, 70-75. [CrossRef]

28. Nambooppha, B.; Rittipornlertrak, A.; Tattiyapong, M.; Tangtrongsup, S.; Tiwananthagorn, S.; Chung, Y.-T.; Sthitmatee, N. Two different genogroups of Ehrlichia canis from dogs in Thailand using immunodominant protein genes. Infect. Genet. Evol. 2018, 63, 116-125. [CrossRef]

29. Zhang, X.; Luo, T.; Keysary, A.; Baneth, G.; Miyashiro, S.; Strenger, C.; Waner, T.; McBride, J.W. Genetic and antigenic diversities of major immunoreactive proteins in globally distributed Ehrlichia canis strains. Clin. Vaccine Immunol. 2008, 15, 1080-1088. [CrossRef]

30. Heinrich, F.; Contioso, V.B.; Stein, V.M.; Carlson, R.; Tipold, A.; Ulrich, R.; Puff, C.; Baumgärtner, W.; Spitzbarth, I. Passagedependent morphological and phenotypical changes of a canine histiocytic sarcoma cell line (DH82 cells). Vet. Immunol. Immunopathol. 2015, 163, 86-92. [CrossRef]

31. Keysary, A.; Waner, T.; Strenger, C.; Harrus, S. Cultivation of Ehrlichia canis in a continuous BALB/C mouse macrophage cell culture line. J. Vet. Diagn. Investig. 2001, 13, 521-523. [CrossRef]

32. Dinarello, C.A. Historical insights into cytokines. Eur. J. Immunol. 2007, 37 (Suppl. S1), S34-S45. [CrossRef]

33. Zhang, J.M.; An, J. Cytokines, inflammation, and pain. Int. Anesthesiol. Clin. 2007, 45, 27-37. [CrossRef]

34. Kelley, L.A.; Mezulis, S.; Yates, C.M.; Wass, M.N.; Sternberg, M.J.E. The Phyre2 web portal for protein modeling, prediction and analysis. Nat. Protoc. 2015, 10, 845-858. [CrossRef]

35. Crowther, J.R. The ELISA Guidebook, 2nd ed.; Humana Press: New York, NY, USA, 2009.

36. AVMA (American Veterinary Medical Association). AVMA Guidelines for the Euthanasia of Animals: 2020 Edition. Available online: https://www.avma.org/sites/default/files/2020-01/2020_Euthanasia_Final_1-15-20.pdf (accessed on 21 June 2020). 
37. Teng, C.H.; Palaniappan, R.U.; Chang, Y.F. Cloning and characterization of an Ehrlichia canis gene encoding a protein localized to the morula membrane. Infect. Immun. 2003, 71, 2218-2225. [CrossRef]

38. Borrathybay, E.; Sawada, T.; Kataoka, Y.; Ohtsu, N.; Takagi, M.; Nakamura, S.; Kawamoto, E. A 39kDa protein mediates adhesion of avian Pasteurella multocida to chicken embryo fibroblast cells. Vet. Microbiol. 2003, 97, 229-243. [CrossRef] [PubMed]

39. Simpson, R.M.; Gaunt, S.D. Immunocytochemical detection of Ehrlichia platys antigens in canine blood platelets. J. Vet. Diagn. Investig. 1991, 3, 228-231. [CrossRef]

40. Rizzardi, A.E.; Johnson, A.T.; Vogel, R.I.; Pambuccian, S.E.; Henriksen, J.; Skubitz, A.P.N.; Metzger, G.J.; Schmechel, S.C. Quantitative comparison of immunohistochemical staining measured by digital image analysis versus pathologist visual scoring. Diagn. Pathol. 2012, 7, 42. [CrossRef] [PubMed]

41. Livak, K.J.; Schmittgen, T.D. Analysis of relative gene expression data using real-time quantitative PCR and the $2^{-\Delta \Delta C T}$ method. Methods 2001, 25, 402-408. [CrossRef] [PubMed]

42. Montojo, J.; Zuberi, K.; Rodriguez, H.; Kazi, F.; Wright, G.; Donaldson, S.L.; Morris, Q.; Bader, G.D. GeneMANIA Cytoscape plugin: Fast gene function predictions on the desktop. Bioinformatics 2010, 26, 2927-2928. [CrossRef]

43. Esteves, I.; Vachiéry, N.; Martinez, D.; Totté, P. Analysis of Ehrlichia ruminantium-specific T1/T2 responses during vaccination with a protective killed vaccine and challenge of goats. Parasite Immunol. 2004, 26, 95-103. [CrossRef]

44. Cárdenas, A.M.; Doyle, C.K.; Zhang, X.; Nethery, K.; Corstvet, R.E.; Walker, D.H.; McBride, J.W. Enzyme-linked immunosorbent assay with conserved immunoreactive glycoproteins gp36 and gp19 has enhanced sensitivity and provides species-specific immunodiagnosis of Ehrlichia canis infection. Clin. Vac. Immun. 2007, 14, 123-128. [CrossRef]

45. Chang-Liu, C.M.; Woloschak, G.E. Effect of passage number on cellular response to DNA-damaging agents: Cell survival and gene expression. Cancer Lett. 1997, 113, 77-86. [CrossRef]

46. Li, J.S.; Yager, E.; Reilly, M.; Freeman, C.; Reddy, G.R.; Reilly, A.A.; Chu, F.K.; Winslow, G.M. Outer membrane protein-specific monoclonal antibodies protect SCID mice from fatal infection by the obligate intracellular bacterial pathogen Ehrlichia chaffeensis. J. Immunol. 2001, 166, 1855-1862. [CrossRef] [PubMed]

47. Winslow, G.M.; Yager, E.; Shilo, K.; Volk, E.; Reilly, A.; Chu, F.K. Antibody-mediated elimination of the obligate intracellular bacterial pathogen Ehrlichia chaffeensis during active infection. Infect. Immun. 2000, 68, 2187-2195. [CrossRef] [PubMed]

48. Ismail, N.; Soong, L.; McBride, J.W.; Valbuena, G.; Olano, J.P.; Feng, H.M.; Walker, D.H. Overproduction of TNF- $\alpha$ by CD8+ Type 1 cells and down-regulation of IFN- $\gamma$ production by CD4+ Th1 cells contribute to toxic shock-like syndrome in an animal model of fatal monocytotropic ehrlichiosis. J. Immunol. 2004, 172, 1786-1800. [CrossRef]

49. Byrom, B.; Obwolo, M.; Barbet, A.F.; Mahan, S.M. A polarized Th1 type immune response to Cowdria Ruminantium infection is detected in immune DBA/2. J. Parasitol. 2000, 86, 983-992. [CrossRef]

50. Esteves, I.; Bensaid, A.; Martinez, D.; Totté, P. IFN- $\gamma$ as an indicator of successful immunization of goats vaccinated with a killed Cowdria ruminantium vaccine. Ann. N. Y. Acad. Sci. 2002, 969, 126-130. [CrossRef]

51. Ismail, N.; Stevenson, H.L.; Walker, D.H. Role of tumor necrosis factor alpha (TNF- $\alpha$ ) and interleukin-10 in the pathogenesis of severe murine monocytotropic ehrlichiosis: Increased resistance of TNF receptor p55- and p75-deficient Mice to fatal ehrlichial infection. Infect. Immun. 2006, 74, 1846-1856. [CrossRef]

52. Stevenson, H.L.; Crossley, E.C.; Thirumalapura, N.; Walker, D.H.; Ismail, N. Regulatory roles of CD1d-restricted NKT cells in the induction of toxic shock-like syndrome in an animal model of fatal ehrlichiosis. Infect. Immun. 2008, 76, 1434-1444. [CrossRef]

53. Stevenson, H.L.; Estes, M.D.; Thirumalapura, N.R.; Walker, D.H.; Ismail, N. Natural killer cells promote tissue injury and systemic inflammatory responses during fatal Ehrlichia-induced toxic shock-like syndrome. Am. J. Pathol. 2010, 177, 766-776. [CrossRef] [PubMed]

54. Warde-Farley, D.; Donaldson, S.L.; Comes, O.; Zuberi, K.; Badrawi, R.; Chao, P.; Franz, M.; Grouios, C.; Kazi, F.; Lopes, C.T.; et al. The GeneMANIA prediction server: Biological network integration for gene prioritization and predicting gene function. Nucleic Acids Res. 2010, 38, W214-W220. [CrossRef] [PubMed] 